\title{
PKM Pemanfaatan Media Sosial \& Aplikasi Pengolahan Angka dalam Peningkatan Penjualan
}

\author{
${ }^{1}$ Gusti Ayu Made Arna Putri, ${ }^{2}$ Ni Wayan Ari Ulandari, ${ }^{3}$ I Nyoman Sri Jaya Kusuma \\ Institut Teknologi dan Bisnis STIKOM Bali \\ Email: gustiayu.arna@gmail.com
}

\begin{abstract}
ABSTRAK
Mitra dalam kegiatan pengabdian masyarakat internal ini adalah usaha kecil dan menengah (UKM) milik Ayu Sukawati yang berlokasi di Jl. Raya Sempidi, No. 59, Badung. Berdasarkan hasil observasi dan wawancara di lapangan diketahui bahwa ada beberapa masalah yang dihadapi oleh UKM milik Ayu Sukawati yaitu kurangnya kemampuan dalam pencatatan transaksi penjualan dan menurunnya pendapatan selama beberapa tahun terakhir. Hal yang menjadi penyebab turunnya pendapatan mitra yaitu banyaknya pesaing di lingkungan sekitar UKM yang berjarak cukup dekat dari warung mitra dan pesaing tersebut juga menjual barang yang sama. Selain itu sistem pemasaran Mitra hanya berkisar di lingkungan desa setempat saja, hal tersebut jelas menjadi penyebab menurunnya pendapatan dari mitra. Upaya pemecahan yang telah dilakukan antara lain 1) pelatihan microsoft excel dalam pencatatan transaksi penjualan, 2) sistem pemasaran dengan pemanfaatan media sosial Instagram yang bertujuan untuk memperluas jaringan pemasaran 3) pembuatan banner yang bertujuan untuk mempermudah customer menemukan lokasi UKM Ayu Sukawati. Metode pelaksanaan pengabdian masyarakat ini adalah metode PALS (participatory action learning system), yakni model pemberdayaan masyarakat dengan tahapan-tahapan kegiatan, (1) penyadaran, (2) pengkapasitasan dan (3) pendampingan. Luaran yang dicapai dari program pengabdian ini adalah (1) publikasi ilmiah melalui jurnal pengabdian masyarakat pada Jurnal Widyabhakti, (2) berhasil mengoprasikan Ms Excel dan dapat melakukan pencatatan transaksi penjualan dengan tingkat keberhasilan 85\%, (3) mitra dapat aktif dalam melakukan pemasaran online melalui Instagram dengan tingkat keberhasilan $80 \%$.
\end{abstract}

Kata kunci : Ms. Excel, Instagram, metode PALS.

\section{ABSTRACT}

Partner in this internal community service activity is a small and medium enterprises (SME) owned by Ayu Sukawati, located on Jl. Raya Sempidi, No. 59, Badung. Based on observations and interviews on the field, there are several problems faced by Ayu Sukawati's SME, i.e. the lack of ability to record sales transactions and declining of income over the past few years. The reason for the decline in Partner's income is the large number of competitors around SME's area, which are quite close to the partners' stall and these competitors are also selling the same goods. Besides Partner's marketing system only around the local village environment, this is clearly the cause of declining partner's income. Resolving efforts 
including 1) Microsoft Excel training in recording sales transactions, 2) marketing system using Instagram social media which aim to expand the marketing network 3) creating banner to make customers find the location of Ayu Sukawati's SME easier. The method of implementing this community service is the PALS (Participatory Action Learning System) method, which is a model of community empowerment with stages of activities, (1) awareness, (2) capacity building and (3) mentoring. Expected outcomes to be achieved from this service program are (1) scientific publications through community service journals in Widyabhakti Journal, (2) succeeded in operating Ms Excel and can record sales transactions with a success rate of $85 \%$, (3) partners can be active in conducting online marketing through Instagram with $80 \%$ success rate.

Keywords: Ms. Excel, Instagram, PALS method.

\section{PENDAHULUAN}

Masyarakat sasaran program kemitraan adalah UKM yang bergerak di bidang penjualan sarana upacara adat Bali. Mitra UKM beralamat di J1. Raya Sempidi, No. 59, Badung atau sekitar 8,3 $\mathrm{km}$ dengan waktu tempuh kurang lebih 20 menit dari kampus STIKOM Bali, Renon (Google Maps, 2020). UKM ini milik Ayu Sukawati yaitu seorang ibu rumah tangga berusia 33 tahun. Pengelolaan UKM Ayu Sukawati dibantu oleh mertua yang berperan sebagai produsen dalam pembuatan sarana upacara tersebut. Mertua Ayu Sukawati merupakan orang yang terampil dalam pembuat segala macam sarana upacara adat Bali. Keahlian dalam pembuatan sarana upacara adat Bali membuatnya berinisiatif membuka warung berukuran $5 \mathrm{~m} \times 6 \mathrm{~m}, 3$ tahun yang lalu tepatnya tahun 2016. Selain dibantu oleh mertua, Mitra juga memiliki beberapa pegawai lepas yang diperbantukan jika sewaktu-waktu pesanan meningkat khususnya pada hari - hari besar agama Hindu.

Proses produksi sarana upacara tersebut dibuat dengan membeli bahan mentah dari supplier yang datang berkala atau membeli langsung ke pasar. Bahan mentah kemudian diolah menjadi seperangkat sarana upacara. Selain membeli dari supplier dan pasar bahan mentah juga bisa dicari di alam baik dari hasil kebun atau pun masyarakat untuk menutupi harga bahan mentah yang naik sewaktu-waktu. Pembuatan sarana ucapacara yang sudah jadi dipasarkan di warung milik Ayu Sukawati. Pemasaran masih sekitar Desa Sempidi saja. Padahal keterampilan dalam pembuatan sarana upacara tidak dimiliki oleh setiap orang.

Barang-barang yang dipasarkan di UKM Ayu Sukawati seperti pejati, prasita biokaonan, segehan, gantung-gantungan, penyepuhan, sampian soda, sampian dapetan, tumpeng, canang sari, nasi soda, canang ceper, dulang daar asep, penyeneng, dll.

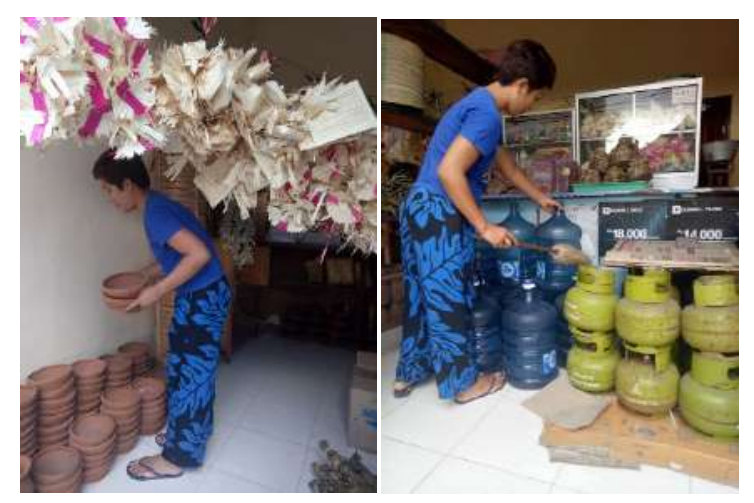




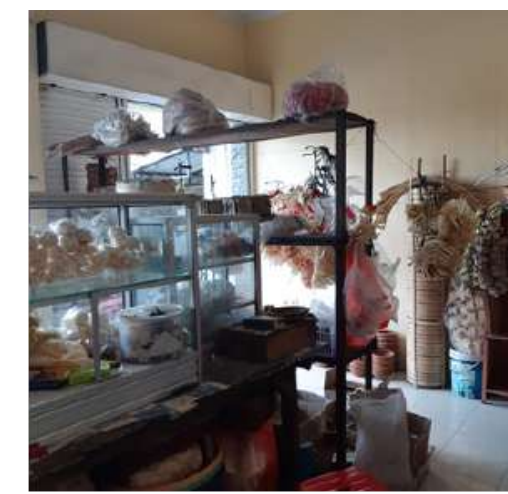

Gambar 1. Produk UKM Ayu Sukawati

Berdasarkan hasil observasi lapangan dan wawancara yang dilakukan pada tanggal 24 September 2019, diketahui bahwa masalah utama yang dihadapi oleh UKM milik Ayu Sukawati adalah kurangnya kemampuan dalam menghitung harga pokok suatu produk. Menurut Bastian Bustami dan Nurlela (2010) harga pokok produksi adalah kumpulan biaya produksi dalam proses awal dan dikurangi persedian produk dalam proses akhir. Menurut Horngren (2008) harga pokok produksi adalah biaya barang yang dibeli untuk diproses sampai selesai, baik sebelum maupun selama periode akuntansi berjalan.

Dalam proses penentuan harga pokok produksi mitra masih merasa bingung jika sewaktu-waktu harga bahan mentah naik sedangkan masih menjual sarana upacara dengan harga yang sama seperti saat bahan baku belum mengalami kenaikan. Menurut Hanggana (2006) bahan baku adalah sesuatu yang digunakan untuk memproduksi produk jadi. Sedangkan menurut Sofjan Assauri (2008), bahan baku adalah semua bahan yang digunakan dalam perusahaan manufaktur, kecuali untuk bahan yang secara fisik dikombinasikan dengan produk yang diproduksi oleh perusahaan manufaktur tersebut. Permasalahan lain yang dihadapi UKM milik Ayu Sukawati adalah banyaknya pesaing di lingkungan Desa Sempidi yang menjual barang yang sama dan berjarak cukup dekat dari UKM Mitra.

Pada awal berdiri UKM Ayu Sukawati cukup ramai sampai tahun berikutnya semakin banyak masyarakat yang berkeinginan untuk membuat usaha dibidang yang sama. Sampai saat ini ada 3 warung pesaing yang berjarak sekitar 300 meter, 200 meter hingga 180 meter dari warung milik Ayu Sukawati. Tahun 2017 UKM Ayu Sukawati mengalami penurunan omset yang pada awalnya Rp. 100.000,-/ hari kini menjadi sekitar Rp. 80.000,-/hari. Penurunan omset Mitra tersebut diakibatkan oleh adanya pesaing di lingkungan tempat UKM Ayu Sukawati.

Berdasarkan fakta yang terungkap dari hasil wawancara dan survei lingkungan sekitar, penulis yakin minimnya keuntungan yang didapat Ayu Sukawati diakibatkan oleh 3 hal yaitu 1) Masalah pertama yang dihadapi UKM Ayu Sukawati adalah kurangnya pengetahuan dalam pencatatan transaksi penjualan, mulai dari pembelian bahan mentah hingga menentukan harga jual produk. 2) Masalah yang kedua adalah banyaknya pesaing di lingkungan UKM Ayu Sukawati yang berjarak cukup dekat dari lokasi UKM Ayu Sukawati. Banyak pesaing dengan jenis UKM yang sama jelas membuat penurunan omset UKM Ayu Sukawati. 3) Masalah ketiga adalah kurangnya tanda pengenal seperti banner yang dipasang didepan warung mengingat lokasi UKM yang berjarak beberapa meter dari jalan utama desa Sempidi. 


\section{RUMUSAN MASALAH}

Berdasarkan analisis situasi tersebut, permasalahan yang dihadapi terkait dengan pelaksanaan program pengabdian masyarakat internal ini adalah rendahnya kemampuan dalam pencatatan transaksi penjualan dan banyaknya pesaing yang berjarak cukup dekat dari UKM Ayu Sukawati. Setelah mempertimbangkan hasil diskusi tim dengan pelaku UKM, analisis skala prioritas permasalahan dan kapasitas pendanaan program pengabdian masyarakat internal ini, maka secara operasional dirumuskan permasalahan yang dihadapi mitra adalah sebagai berikut:

1. Kemampuan pencatatan transaksi penjualan masih sangat rendah. Pada awal pembelian bahan mentah sampai menjadi barang yang siap dipasarkan masih menggunakan perhitungan manual sehingga nilai keuntungan tidak dapat dihitung secara terperinci. Keuntungan rata-rata UKM Ayu Sukawati perbulan hanya dapat diperkirakan saja tanpa melalui perhitungan yang jelas dan detail.

2. Hasil wawancara mendalam dan observasi langsung di lapangan menjadikan peneliti yakin masalah utama penurunan omset UKM milik Ayu Sukawati adalah banyaknya pesaing dilingkungan tempat UKM Ayu Sukawati. Sistem pemasaran juga hanya dilingkungan desa Sempidi saja sehingga minimnya konsumen dari desa lain.

3. Hasil observasi langsung di lokasi juga menunjukkan tidak adanya tanda pengenal UKM milik Ayu Sukawati, seperti nama warung, alamat, nomor telpon. Hal tersebut sangat membantu konsumen untuk mencari alamat UKM Ayu Sukawati melihat lokasi UKM juga berjarak beberapa meter dari jalan utama desa Sempidi.

\section{METODE}

Metode pelaksanaan dalam pengabdian masyarakat ini yaitu metode PALS (participatory action learning system). Metode PALS dikembangkan oleh Linda Mayoux tahun 2002 (Mayoux, 2005).

PALS merupakan paradigma baru dalam Program Pengabdian Masyarakat (PPM) yang bersifat problem solving, komprehensif, bermakna, tuntas, dan sustainable. Metode PALS merupakan metode pemberdayaan masyarakat dengan tahapan-tahapan kegiatan, yakni (1) tahap penyadaran (awareness) merupakan tahap inisiasi untuk menyadarkan UKM agar memahami kondisi dan potensi usahnya, serta upaya inovatif yang dapat dilakukan untuk meningkatkan penghasilan, (2) tahap pengkapasitasan (participating) adalah tahap pelibatan partisipasi aktif seluruh anggota UKM untuk membangun, mengelola, dan membesarkan usaha produktifnya, dan (3) tahap pendampingan (scaffolding) adalah tahap pengawalan aktivitas UKM dalam memberdayakan dirinya secara berkelanjutan (Agustino, 2020).

\section{PEMBAHASAN}

Kegiatan pengabdian masyarakat internal ITB Stikom Bali memperoleh hasil sebagai berikut:

\section{A. Pencatatan Transaksi Penjual}

Proses pencatatan transaksi penjual dimulai dari pembuatan kode barang, kemudian penentuan harga jual setelah itu barulah total keuntungan dihitung. 


\section{Pembuatan Kode barang}

Pembuatan kode barang dimulai dengan mencatat seluruh nama barang atau produk yang akan atau sudah siap dipasarkan.

Berikut bentuk tampilan kode barang serta penjelasannya:

Tabel 1. Kode Barang

\begin{tabular}{|c|l}
\hline \multicolumn{2}{|r}{ PENAMAAN KODE B } \\
\hline Kode & \multicolumn{1}{|c}{ Nama Barang } \\
\hline 010 & Ceper Gede \\
\hline 011 & Ceper Kecil \\
\hline 012 & Daksina \\
\hline 013 & Dapetan Tumpeng P \\
\hline 014 & Dulang Kecil \\
\hline 015 & Dupa \\
\hline
\end{tabular}

Dalam pencatatan nama barang lebih dari 40 produk telah dicatat dan diberi kode, terdapat 10 produk yang menjadi sampel dan dipilih secara acak. Pada tabel "Penamaan Kode Barang" terdapat kode, nama barang dan satuan.

\section{Penentuan Harga Jual}

Penentuan harga jual produk dimulai dengan perhitungan harga pokok sesuai dengan harga pokok saat itu, biaya-biaya yang dikeluarkan baik itu biaya pengiriman atau pembuatan dan berapa keuntungan yang diinginkan mitra.

Bentuk tampilan penentuan harga jual dibagi dalam 3 tabel sebagai berikut:
Tabel 2. Penentuan Harga Jual dengan Input Harga Pokok

\begin{tabular}{|c|c|c|c|c|c|c|c|c|}
\hline \multicolumn{9}{|c|}{ PEATMTUAN HARGA UUAL } \\
\hline & Nama Barang & Satuan & Hanke poksok & & Vatatasiony & Blays & Unturgs & Hartia Jual \\
\hline alo & Coger Gede & Fat & 20,000 & \multirow{2}{*}{\multicolumn{2}{|c|}{$\begin{array}{l}\text { MASUKKAN HARGA } \\
\text { POKOK BARANG }\end{array}$}} & & 3000 & 12,000 \\
\hline 011 & Ceser Kectil & aat & 8,000 & & & & 1000 & 10,000 \\
\hline 012 & Daksina & Palast & Ga000 & & & & 1,000 & 8,000 \\
\hline 013 & Dapecen Tumpeng Pil & weanter & 800,000 & 50,000 & Permbuarsan & & $\operatorname{san}, 00$ & 300,000 \\
\hline 014 & Duleng $K=$ di & 8iii & 25000 & 1,000 & Ongkif & & 2500 & 5,000 \\
\hline 015 & Dupa & Bungkus & 11,000 & 1,000 & Ongkir & & 3,000 & 15,000 \\
\hline 020 & Noes Yasa & Pakst & 18,000 & 4,000 & Permbuatar & & 3,000 & 25,000 \\
\hline 024 & एक्षित & Paker & 35,000 & 5,000 & Permbuatas & & $10,0 x$ & 50,000 \\
\hline 026 & Pengulasan & Paktat & 27,000 & 2,000 & Pentibuatan & & 10000 & 200000 \\
\hline 028 & Prasesta Bulikaonan & Pakst & 20,000 & 5,000 & Pembuatson & & s,000 & 30,000 \\
\hline
\end{tabular}

Pada tabel "Penentuan Harga Jual dengan Input Harga Pokok" dimulai dengan memasukkan harga pokok barang. Nilai harga pokok barang dapat diganti apabila terjadi kenaikan atau penurunan pada harga bahan pokok tersebut sehingga harga jual akan tetap stabil.

Tabel 3. Penentuan Harga Jual dengan Input Biaya

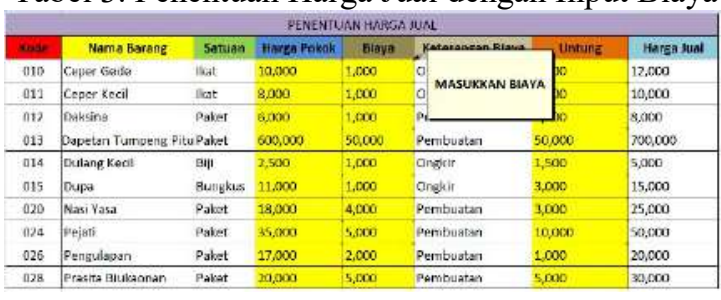

Pada tabel "Penentuan Harga Jual dengan Input Biaya" besar biaya yang masuk dalam sistem tergantung dari biaya pengiriman barang dan tingkat kesulitan dalam pembuatan produk.

Tabel 4. Penentuan Harga Jual dengan Input Keuntungan

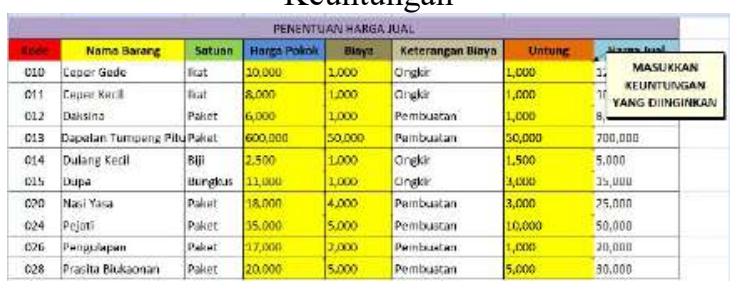


Pada tabel "Penentuan Harga Jual dengan Input Keuntungan" besar kecilnya keuntungan yang masuk dalam sistem diperoleh berdasarkan keuntungan yang diinginkan oleh mitra sebagai pemilik usaha.

\section{Perhitungan Total Keuntungan}

Perhitungan total keuntungan dimulai dengan memasukkan kode barang dan jumlah barang berdasarkan kurun waktu tertentu baik itu total keuntungan harian, mingguan, bulanan maupun tahunan.

Bentuk tampilan penentuan total keuntungan dibagi dalam 2 tabel sebagai berikut:

Tabel 5. Perhitungan Total Keuntungan dengan Input Kode Barang

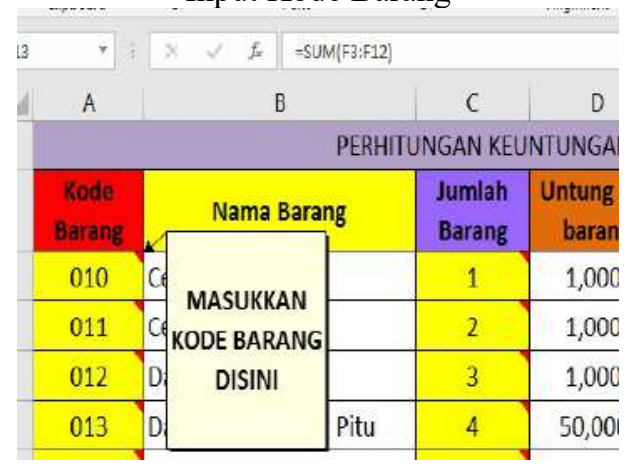

Pada tabel "Perhitungan Total Keuntungan dengan Input Kode Barang" dimulai dengan memasukkan kode barang yang keuntungannya ingin diketahui. Kemudian muncul nama barang tersebut, selanjutnya masukkan jumlah barang yang terjual seperti pada tabel "Perhitungan Total Keuntungan dengan Input Jumlah Barang”.
Tabel 6. Perhitungan Total Keuntungan dengan Input Jumlah Barang

\begin{tabular}{|c|c|c|c|c|}
\hline$+n$ & \multicolumn{2}{|l|}{. } & \multicolumn{2}{|r|}{, } \\
\hline - & $x \vee f=$ & $=$ SUMMF:F:F12 & & \\
\hline A & \multicolumn{2}{|c|}{ B } & c & D \\
\hline \multicolumn{5}{|c|}{ PERHITUNGAN KEUNTUNGAI } \\
\hline $\begin{array}{l}\text { Kode } \\
\text { Barang }\end{array}$ & \multicolumn{2}{|c|}{ Nama Barang } & $\begin{array}{l}\text { Jumlah } \\
\text { Barang }\end{array}$ & $\begin{array}{l}\text { Untung } \\
\text { haman }\end{array}$ \\
\hline 010 & \multicolumn{2}{|l|}{ Ceper Gede } & 1 & MAS \\
\hline 011 & \multicolumn{2}{|l|}{ Ceper Kecil } & 2 & RAI \\
\hline 012 & \multicolumn{2}{|l|}{ Daksina } & 3 & D \\
\hline 013 & \multicolumn{2}{|c|}{ Dapetan Tumpeng Pitu } & 4 & उण,00 \\
\hline
\end{tabular}

Pada tabel "Perhitungan Total Keuntungan dengan Input Jumlah Barang" jumlah barang terjual dihitung berdasarkan periode waktu tertentu. Perhitungan total keuntungan diperoleh berdasarkan keuntungan harian, mingguan, bulanan dan tahunan.

\section{B. Membuatan Akun Instagram}

Proses pembuatan akun Instagram dimulai dari pengambilan foto produk, pengumpulan dan seleksi foto produk, dilanjutkan dengan pemberian watermark hingga proses upload foto ke Instagram. Penambahan follower selanjutnya dilakukan karena dirasa perlu dalam tahap promosi, selain itu dalam tahap pengujian statistik pada Instagram Bisnis tidak bisa dilakukan jika jumlah follower kurang dari 1000 follower.

Berikut dibahas lebih rinci langkahlangkah yang dilakukan:

\section{Photoshoot produk}

Proses pengambilan foto di warung Sarwa Ledang milik UKM Ayu Sukawati yang dilakukan oleh anggota mahasiswa pengabdian masyarakat. 


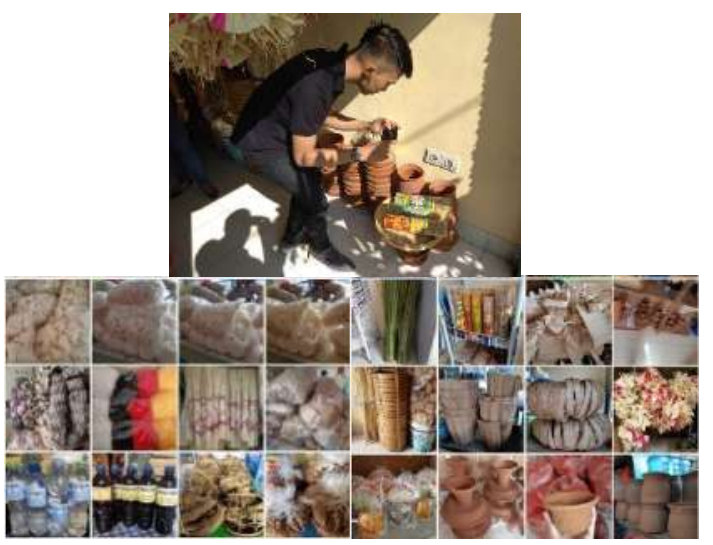

Gambar 2. Photoshoot produk

Dari puluhan foto produk yang telah diambil dipilih beberapa gambar terbaik sehingga diperoleh 31 foto pada unggahan awal di Instagram. Selanjutnya dilakukan pemberian watermark.

\section{Pengisian Watermark}

Watermark adalah sebuah tulisan atau logo yang biasa ditemukan pada sebuah karya digital atau manual. Menurut Cahyadi (2007) watermarking merupakan teknik penyisipan data ke dalam elemen multimedia seperti citra, audio atau video. Menurut Rajarathnam et. all (2002). teknik digital watermarking dapat diaplikasikan dalam berbagai hal seperti penanda kepemilikan dari dokumen multimedia sehingga data dapat dilindungi dengan menambahkan watermark yang berisi informasi pemilik dari dokumen multimedia. Tujuan dari pengisian watermark untuk setiap produk yaitu sebagai identitas pengenal dari pencipta produk tersebut. Selain itu, watermark juga digunakan untuk menghindari pengambilan foto secara ilegal pada media online.
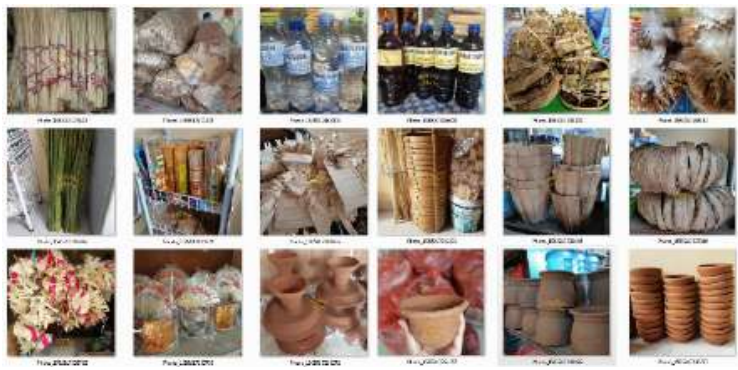

Gambar 3. Pengisian watermark

Pengisian watermark dilakukan dengan aplikasi "Add Watermark" yang bisa diunduh dengan mudah melalui Playstore. Penggunaan aplikasi via handphone bertujuan agar mitra lebih murah saat pengisian watermark dikemudian hari. Sehingga mitra dapat melakukan pengambilan foto, pengisian watermark hingga upload foto dengan mudah dan cepat tanpa bantuan laptop.

\section{Pembuatan akun Instagram}

Proses pembuatan akun Instagram dimulai dari pembuatan alamat email yaitu sarwaledang1992@gmail.com, kemudian dilakukan pengisian biodata seperti nama akun "Warung Sarwa Ledang", username "warung_sarwaledang"dan password.

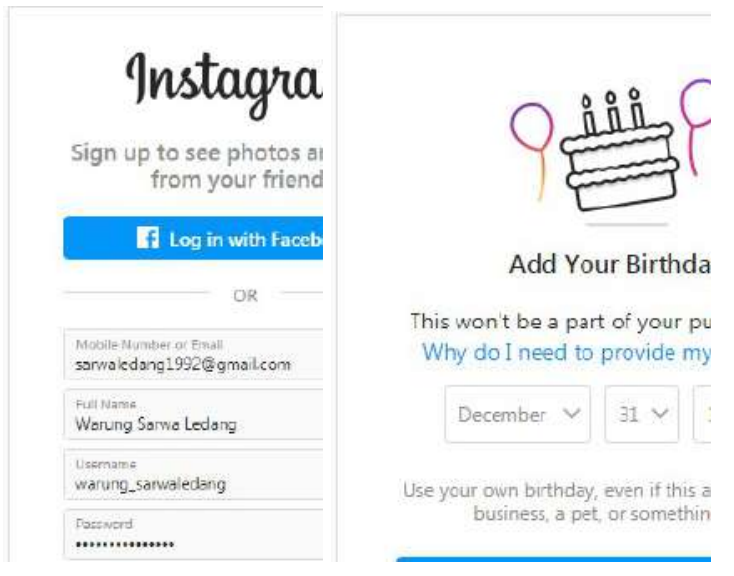

Gambar 4. Pengisian data diri 
Periksa kembali pengisian data pada akun baru instagram, pastikan nama akun belum pernah digunakan. Lanjutkan ke tahap sign up akan muncul pengisian tanggal, bulan dan tahun lahir. Pada bagian ini, peneliti sudah mengkonfirmasi dengan mitra untuk tahun warung Sarwa Ledang berdiri yaitu pada tahun 1992, akan tetapi untuk tanggal dan bulan mitra tidak ingat kapan tepatnya warung tersebut berdiri sehingga dibuat 31 Desember 1992 atas kesepakatan bersama.

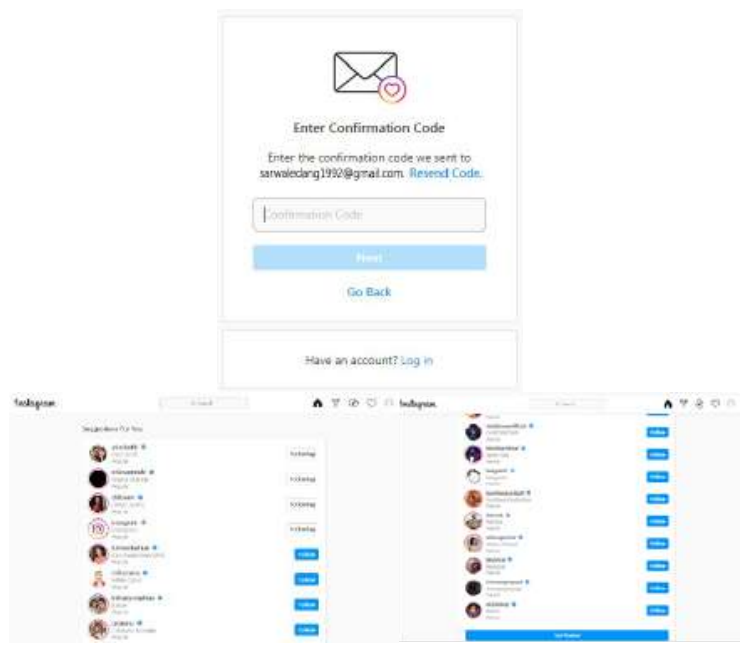

Gambar 5. Konfirmasi kode dan pemilihan follower

Langkah berikutnya setelah pengisian tanggal lahir yaitu melanjutkan ke tahap resent code, buka kembali email sarwaledang1992@gmail.com akan dikirimkan 6 digit angka yang diisi pada laman enter confirmation code. Setelah kode terisi dengan benar lanjutkan dan akan muncul laman permintaan teman dari kita. Pilih beberapa teman secara acak sebelum meminta pertemanan dari saudara, teman atau kerabat.

\section{Posting foto pada Instagram}

Pada instagram yang telah terdaftar mulai lakukan penginputan atau posting foto yang sebelumnya telah diseleksi dan diberi watermark.

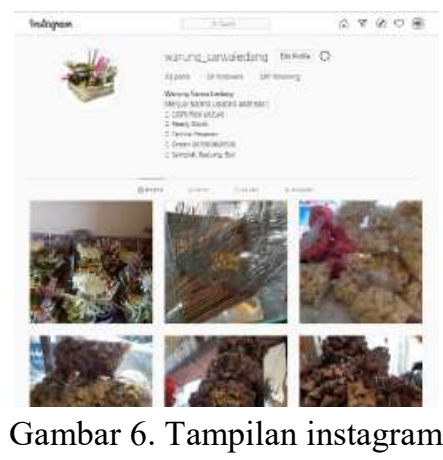

Selain melakukan posting foto, ubah biodata pada edit profile ketikan seperti jenis produk yang dijual, gambar atau foto yang dijual $100 \%$ gambar asli produk, barang selalu tersedia, menerima pesanan yang dapat diorder pada nomor telpon atau WhatsApp yang tertera dan alamat warung Sarwa Ledang. Tujuan dari pengisian deskripsi warung yaitu agar pelanggan lebih mudah dalam berkomunikasi dan mencari alamat warung. Penting juga dilakukan untuk mengubah profile picture agar tampilan lebih menarik dan tepat sasaran.

\section{Penambahan Follower}

Melihat dari perkembangan kunjungan pada laman Instagram yang dirasa masih rendah terlihat dari jumlah like, maka dibutuhkan strategi lain untuk menarik masyarakat. Salah satu strategi yang sering dilakukan oleh para pedagang online adalah pembelian follower. Tujuan dari membeli follower yaitu selain menambah jumlah masyarakat yang melihat akun tersebut juga memberi kepercayaan masyarakat bahwa akun tersebut aktif dan 
nyata. Strategi penambahan follower juga dirasa perlu karena saat ini jumlah follower Warung Sarwa Ledang terhitung 19 follower masih sangat jauh dari yang diharapkan.

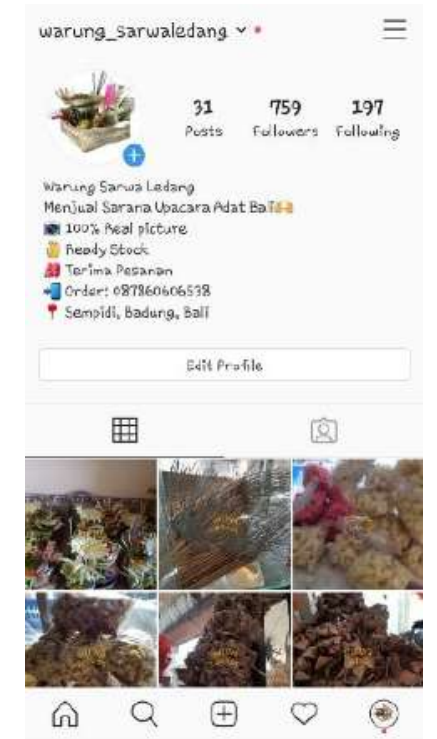

Gambar 7. Penambahan follower

Langkah penambahan follower dilakukan, sehingga kini jumlah follower Warung Sarwa Ledang berjumlah 759 follower. Perkembangan jumlah follower akan terus diamati sehingga penjualan secara online dapat membantu peningkatan jumlah pembeli di warung tersebut.

\section{Pengukuran Kinerja Instagram}

Salah satu kelebihan dari berjualan online melalui Instagram yaitu pengguna dapat melakukan pengukuran kinerja akun yang sedang dikelola. Pengukuran kinerja akun dapat dilihat di bagian insight pada laman akun Instagram pengguna. Bagian insight bermanfaat dan membantu dalam mempelajari tentang kinerja serta aktivitas akun di Instagram. Pengguna akan menemukan data-data seperti jenis kelamin, rentang usia, dan lokasi. Pengguna juga dapat melihat konten dengan aktivitas yang paling banyak serta mendapatkan interaksi dari para pengguna Instagram (Instagram, 2020).

Sebelum memulai untuk melihat dan melakukan pengecekan pada bagian insight, pastikan pengguna mengonversi profil menjadi akun bisnis.

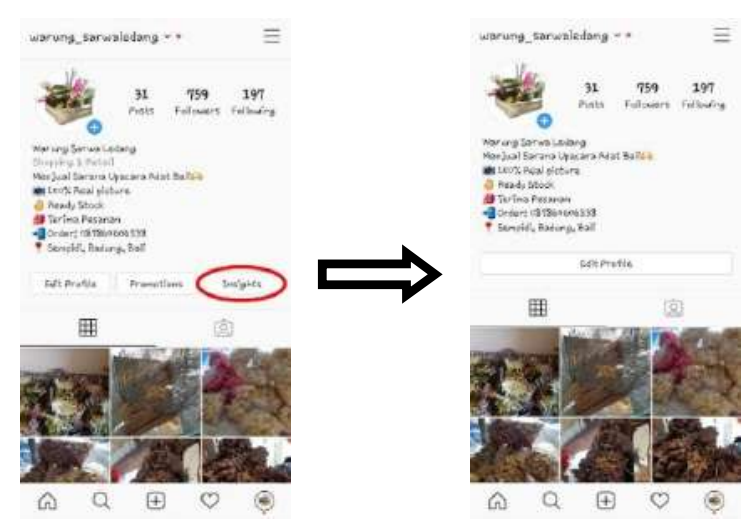

Gambar 8. Konversi akun personal menjadi akun bisnis

Berikut tampilan data pada bagian insight di laman akun Instagram pengguna.

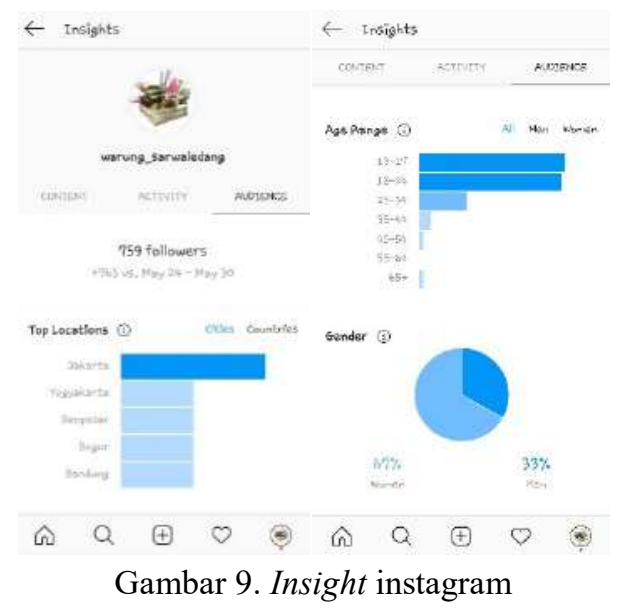


Data yang ditampilkan pada bagian insight seperti lokasi dari follower Instagram yang didominasi oleh pengguna Instagram di Jakarta. Hal tersebut disebabkan oleh pembelian follower Instagram yang hanya bisa dilakukan dalam skala negara bukan kota atau daerah. Selain itu, rentang umur dari follower Instagram juga dapat dilihat pada bagian insight. Terlihat bahwa follower dengan rentang umur $13-24$ tahun paling banyak mengikuti akun tersebut. Tidak hanya lokasi dan umur yang dapat dipantau dari bagian insight namun juga jenis kelamin dari follower Instagram yang mana $67 \%$ didominasi oleh perempuan dan $33 \%$ sisanya laki-laki.

Data pada bagian insight dapat berubah sewaktu-waktu tergantung dari aktivitas pengguna dalam mengelola akun Instagram. Aktivitas yang dapat dilakukan untuk meningkatkan kinerja akun seperti rajin dalam mengunggah konten, mencari follower serta melakukan promosi. Sehingga dalam perkembangan aktivitas promosi melalui Instagram, masih tetap dilakukan pantauan secara berkala dari tim pengabdian masyarakat.

\section{Pembuatan Banner}

Merujuk pada rumusan masalah tentang kurangnya tanda pengenal pada Warung Sarwa Ledang sehingga solusi yang dapat dilakukan yaitu pembuatan banner. Jenis banner yang dibuat yaitu standing banner yang dibuat dan dipilih berdasarkan diskusi dengan mitra.

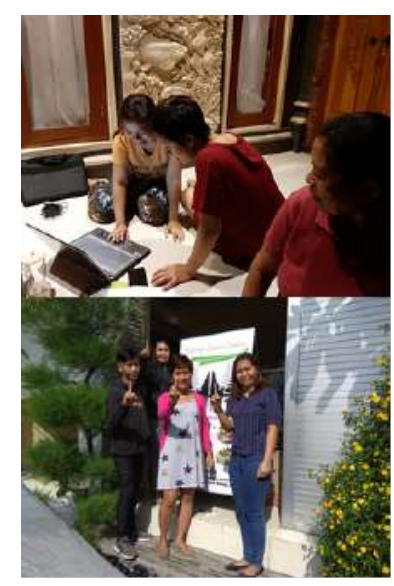

Gambar 10. Pembuatan Banner

Setelah melakukan diskusi baik secara langsung maupun via Whatsapp dipeloleh kesepakatan bahwa desain banner seperti foto pertama pada gambar diatas. Desain yang dibuat berisikan nama warung, barang-barang yang jual, nomor telpon, alamat situs online maupun offline. Tanpa menunggu waktu lama standing banner segera dicetak dan diberikan kepada mitra. Respon mitra sangat baik karena sekarang Warung Sarwa Ledang memiliki identitas yang dapat memudahkan konsumen dalam mencari lokasi warung.

\section{EVALUSI KEGIATAN}

Evalusi kegiatan dalam pengabdian masyarakat internal disajikan secara kuantitatif sebagai berikut:

Tabel 7. Evaluasi Kegiatan

\begin{tabular}{|l|c|c|c|}
\hline No & Target Luaran & $\begin{array}{c}\text { Indikator } \\
\text { Pencapaian }\end{array}$ & $\begin{array}{c}\text { Kuan } \\
\text { titatif }\end{array}$ \\
\hline \multicolumn{3}{|l|}{$\begin{array}{l}\text { Masalah 1: Kurangnya kemampuan dalam } \\
\text { pencatatan transaksi penjualan }\end{array}$} \\
\hline
\end{tabular}




\begin{tabular}{|c|c|c|c|}
\hline No & Target Luaran & $\begin{array}{l}\text { Indikator } \\
\text { Pencapaian }\end{array}$ & $\begin{array}{l}\text { Kuan } \\
\text { titatif }\end{array}$ \\
\hline 1 & $\begin{array}{l}\text { Berhasil } \\
\text { mengoperasikan } \\
\text { Ms Excel } \\
\text { sehingga dapat } \\
\text { melakukan } \\
\text { pencatatan } \\
\text { transaksi } \\
\text { penjualan, } \\
\text { penentuan harga } \\
\text { jual dan } \\
\text { perhitungan } \\
\text { keuntungan } \\
\text { dengan lebih } \\
\text { terperinci. }\end{array}$ & $\begin{array}{l}\text { Berhasil } \\
\text { mengoperasikan } \\
\text { Ms Excel dan } \\
\text { dapat } \\
\text { melakukan } \\
\text { pencatatan } \\
\text { transaksi } \\
\text { penjualan, } \\
\text { penentuan } \\
\text { harga jual dan } \\
\text { perhitungan } \\
\text { keuntungan } \\
\text { namun masih } \\
\text { perlu dibantu } \\
\text { untuk input } \\
\text { kode barang. }\end{array}$ & $85 \%$ \\
\hline \multicolumn{4}{|c|}{$\begin{array}{l}\text { Masalah 2: Ada } 3 \text { pesaing yang berada cukup } \\
\text { dekat dengan UKM }\end{array}$} \\
\hline 2 & $\begin{array}{l}\text { UKM Ayu } \\
\text { Sukawati dapat } \\
\text { aktif dalam } \\
\text { pemasaran } \\
\text { online melalui } \\
\text { Instagram, } \\
\text { melihat pesaing } \\
\text { yang menjual } \\
\text { barang yang } \\
\text { sama berjarak } \\
\text { cukup dekat } \\
\text { dengan lokasi } \\
\text { UKM Ayu } \\
\text { Sukawati. }\end{array}$ & $\begin{array}{l}\text { UKM Ayu } \\
\text { Sukawati cukup } \\
\text { aktif dalam } \\
\text { pemasaran } \\
\text { online melalui } \\
\text { Instagram, } \\
\text { namun tetap } \\
\text { harus dipantai } \\
\text { dapat hal } \\
\text { upload foto, dan } \\
\text { pemasaran di } \\
\text { beberapa media } \\
\text { online. }\end{array}$ & $80 \%$ \\
\hline \multicolumn{4}{|c|}{$\begin{array}{l}\text { Masalah 3: kurang tanda pengenal di depan } \\
\text { warung }\end{array}$} \\
\hline 3 & $\begin{array}{l}\text { Pembuatan } \\
\text { banner di depan } \\
\text { UKM Ayu } \\
\text { Sukawati dapat } \\
\text { mempermudah } \\
\text { pembeli dalam } \\
\text { mencari lokasi } \\
\text { dan terlihat lebih } \\
\text { menarik. }\end{array}$ & $\begin{array}{l}\text { Banner di } \\
\text { depan warung } \\
\text { UKM Ayu } \\
\text { Sukawati telah } \\
\text { dipasang } \\
\text { dengan baik. }\end{array}$ & $100 \%$ \\
\hline
\end{tabular}

\section{SIMPULAN}

Pada pengabdian masyarakat Internal diperoleh kesimpulan bahwa telah dilakukan pelatihan tentang pencatatan transaksi keuangan dari pembuatan kode barang, penetapan harga jual dan perhitungan keuntungan dengan bantuan Ms Excel. Pelatihan tersebut menjadikan Mitra lebih paham tentang pencatatan keuangan dengan sistem yang cepat, praktis dan canggih dengan tingkat keberhasilan sebesar $85 \%$ karena mitra masih memerlukan bantuan dan latihan dalam proses input kode barang.

Selain pelatihan Ms. Excel, tim pengabdian masyarakat juga membantu dalam penjualan online dengan Instagram. Mulai dari pembuatan, pelatihan hingga pemantauan kinerja akun Instagram. Pembuatan Instagram bertujuan untuk meningkatkan penjualan mitra yang awalnya hanya offline kini berkembang menjadi online. UKM Ayu Sukawati cukup aktif dalam pemasaran online melalui Instagram dengan tingkat keberhasilan $80 \%$, angka tersebut diperoleh berdasarkan kemampuan mitra dalam mengoperasikan media sosial dan tingkat penjualan yang terus bertambah.

Tim pengabdian masyarakat juga sangat teliti dalam melihat kondisi warung, tampak belum terdapat papan identitas warung sehingga dibuatkan standing banner. Tujuan dibuatkannya standing banner yaitu selain sebagai identitas warung juga untuk memudahkan masyarakat mencari lokasi Warung Sarwa Ledang.

\section{UCAPAN TERIMA KASIH}

Terima kasih yang sebesarbesarkannya kepada semua pihak yang telah membantu terselenggaranya 
pengabdian masyarakat yang berjudul "Pkm Pemanfaatan Media Sosial \& Aplikasi Pengolahan Angka Dalam Peningkatan Penjualan". Kepada Bapak Dr. Dadang Hermawan sebagai Rektor Institut Teknologi Dan Bisnis Stikom Bali yang telah memberikan kesempatan untuk melakukan pengabdian dengan bantuan dana melalui Institut Teknologi Dan Bisnis Stikom Bali, Ibu Dr. Evi Triandini, M.Eng Pengabdian Masyarakat Institut Teknologi Dan Bisnis Stikom Bali yang telah membantu memfasilitasi hingga pengabdian ini dapat berjalan dengan lancer, mitra PKM yang telah membantu dan ikut terlibat dalam proses pembuatan pengabdian ini dan seluruh rekan yang telah memberikan dukungan moral kepada penulis.

\section{DAFTAR PUSTAKA}

Agustino, D. P. (2020). Intensifikasi Strategi Promosi UKM Balietnik Butik Berbasis Blended Promotion \& Pageants. Jurnal Ilmiah Populer Widyabhakti, 2(2), 7-13

Assauri, S. 2008. Manajemen Produksi dan Operasi. Jakarta: Fakultas Ekonomi Universitas Indonesia

Bustami, Bastian dan Nurlela. 2010. Akuntansi Biaya. Edisi kedua. Jakarta: Mitra Wacana Media

Cahyana, T., Basarudin dan Jaya, D. 2007. Teknik Watermarking Citra berbasis SVD. Jakarta: National Conference on Computer Science \& Information Technology 2007
Chandramouli, R., Memon, N., dan Rabbani, M. 2002. Digital Watermarking. Encyclopedia of Imaging Science and Technology. NewYork: Wiley

Google Maps. (2020). Melihat Alamat J1. Raya Sempidi No.59, Sempidi. [Online] tersedia: https://goo.gl/maps/2RvCdMSTtNwU 3Pod9 [diakses tanggal 2 Juni 2020]

Hanggana, S. 2006. Prinsip Dasar Akuntansi Biaya. Surakarta: Mediatama.

Horngren, C. T., Srikant, M. D., \& Foster, G. 2008. Akuntansi Biaya: Penekanan Manajerial. Jilid Pertama, Edisi Kesebelas. Jakarta: Indeks

Instagram. (2020). Melihat Insights di Instagram. [Online] tersedia : https://help.instagram.com/153393382 0244654?helpref=page contet [diakses tanggal 20 Mei 2020]

Mayoux, L. 2005. Participatiory Action Learning System. Training Manual. Sudan: Part Sudan Association for Small Enterprise Development (PASED) 